\title{
Measuring severity of injuries to children from home accidents
}

\author{
R ALWASH AND M MCCARTHY \\ Department of Community Medicine, University College London
}

SUMmaRY The severity of injuries from home accidents was assessed in 402 children under the age of 5 treated in the accident department of an inner London hospital. Our child injury severity scale comprises three grades of severity for six types of injury. There was moderate agreement between the observer and an assessor in categorising the cases. Burns and scalds and poisoning caused more severe injuries than other accidents. A strong correlation was found between the parent's social class and the severity of the accident, but there was no correlation with ethnic group as indicated by the parents' country of birth. The development of a reliable scale of severity is important if programmes of prevention of accidents to children in the home are to be evaluated successfully.

Accidents are an important cause of mortality and morbidity in children. ${ }^{1}$ About one in six children each year in Britain are injured severely enough to attend an accident and emergency department. In a population study $44 \%$ of children were reported to have had an accident that warranted medical treatment before they were 5 years old; about two thirds of these accidents were in the home, and less than $5 \%$ on the roads. ${ }^{2}$ More detailed epidemiological studies of accidents to children at home have sought to identify causal factors and suggest ways of prevention. ${ }^{3-6}$

Measures of the severity of injuries are important because plans for prevention might seek to reduce the severity of the injuries, rather than their frequency. Previous studies of accidents to children at home have varied in the composition of subjects and their accidents, as well as in the methods used for measuring the severity of the injuries. Simple ${ }^{7}$ or more detailed ${ }^{89}$ classifications may be made from the medical care given, but the admission of children to hospital depends on social factors as well as on the severity of the injury. The American abbreviated injury scale, designed to assess the severity of injuries to adults in road traffic accidents, has clear grades of injury. The abbreviated injury scale seems, however, to have low discriminating power for accidents to children; in one study it classified $89 \%$ of children as having a minor injury, $8 \%$ as moderate, and remainder severe (including fatal). ${ }^{5}$

We have developed a scale to measure the severity of all accidents to children at home that were treated in the accident department of an inner city hospital. It is based on the scale used by Illingworth in her study of injuries in playgrounds, ${ }^{11}$ and has clear definitions and a broad distribution of injuries among categories.

\section{Methods}

The measurement of severity was part of a study designed to describe the frequency and types of accidents that happen to children under five in the home in a multiracial population, and to relate these to the home environment. ${ }^{12} 13$ The study was done in the Central Middlesex hospital, which draws patients from two boroughs in west London. Ethical permission was given by Brent District Health Authority. Details were recorded of all accidents to children under five that happened in the home who were treated in the accident department over a 10 month period in 1983-4.

Because our primary aim was to study accidents in the home, the commonest type of accident in this age group, data were not recorded about other types of accidents. Children given reassurance alone without treatment, children from outside the main catchment area, and 22 children with non-accidental injuries were excluded. A total of 481 children were eligible for the study. The records of the accident department were reviewed each week (by RA) and permission to visit the parents was sought by letter. 
There were 79 children whose parents refused or who could not be contacted, a response rate of $83 \%$, leaving a sample of 402 parents who were interviewed.

The hospital catchment population for the study covered 21 electoral wards. Data from the 1981 census showed that this was a multiracial and relatively deprived part of London. Three main ethnic groups were defined by the parents' country of birth: British (including the Republic of Ireland), Caribbean, and Asian (predominantly from the Indian subcontinent). The remainder comprised other European and black African parents. Social class was assigned by the Registrar General's classification; this particular population had a proportion of unclassifiable parents because of the high rate of unemployment.

We divided the accidents in the home into six types and classified the injuries retrospectively using information from clinical records of the accident department, the inpatient notes, and the records of the community nurses. The child injury severity scale had definitions for three grades-mild, moderate, and severe (table 1). To test the reliability of the scale, short descriptions of all 402 accidents were written down by the researcher (RA) and scored afterwards by another assessor (MM). The kappa statistic was used to test interobserver agreements. ${ }^{14}$

\section{Results}

Classification by the researcher and assessor into the three grades of severity is shown in table 2 . Using the scale, the researcher identified that $36 \%$ of accidents were mild, $39 \%$ moderate, and $24 \%$ severe. The kappa statistic $(0.58)$ indicated moderate interobserver agreement. The observers had similar distributions in their disagreements among the categories, suggesting that the differences between them were random rather than systemitic.

Accidents were classified as falls, burns and scalds, poisoning, cuts, and 'other'. Almost half $(n=195,48 \%)$ of all the accidents, were falls, and most of these were of mild or moderate severity. Table 3, however, shows that some other types of accident-for example, burns and scalds $(n=49$, $12 \%)$, and poisoning $(n=63,16 \%)-$ stand out as being relatively more severe.

The electoral wards were grouped according to rates of attendance for children in the study compared with their populations of children recorded in the 1981 census. There were five high wards (over 50 attending/1000 children), nine medium (26-50/ 1000 ), and seven low (up to $25 / 1000$ ). There was no correlation between the number of children attend-
Table 1 Injury severity scale

\begin{tabular}{|c|c|}
\hline \multicolumn{2}{|l|}{ Lacerations } \\
\hline Mild: & $\begin{array}{l}\text { minor, no treatment } \\
\text { minor. suture only }\end{array}$ \\
\hline Moderate: & $\begin{array}{l}\text { requiring further treatment or dressings } \\
\text { multiple, with hacmatoma } \\
\text { joint injuries needing immobilisation } \\
\text { accompanied by swelling. contusion. or effusion }\end{array}$ \\
\hline Severe: & requiring admission to hospital \\
\hline \multicolumn{2}{|c|}{ Burns and scalds } \\
\hline Mild: & minor, no further treatment \\
\hline Moderate: & requiring one or two dressings at home \\
\hline Severe: & $\begin{array}{l}\text { requiring more than two dressings at home or } \\
\text { admission to hospital }\end{array}$ \\
\hline \multicolumn{2}{|l|}{ Poisoning } \\
\hline Mild: & requiring reassurance only \\
\hline Moderate: & $\begin{array}{l}\text { requiring admission to hospital for } 24 \text { hours or } \\
\text { short term treatment }\end{array}$ \\
\hline Severe: & requiring admission to hospital for several days \\
\hline \multicolumn{2}{|l|}{ Fractures } \\
\hline Mild: & none included \\
\hline Moderate: & $\begin{array}{l}\text { undisplaced, followed up as outpatient } \\
\text { accompanied by lacerations }\end{array}$ \\
\hline Severe: & $\begin{array}{l}\text { with deformity or displacement, or both } \\
\text { requiring admission to hospital } \\
\text { requiring operation under general anaesthetic }\end{array}$ \\
\hline \multicolumn{2}{|l|}{ Head injuries } \\
\hline Mild: & requiring reassurance only \\
\hline Moderate: & $\begin{array}{l}\text { accompanied by another injury (laceration. } \\
\text { hacmatoma, or bruise) }\end{array}$ \\
\hline Severe: & $\begin{array}{l}\text { requiring admission to hospital, accompanied } \\
\text { by clinical signs } \\
\text { fractured skull with prolonged loss of } \\
\text { consciousness }\end{array}$ \\
\hline \multicolumn{2}{|c|}{ Foreign body (either stuck or swallowed) } \\
\hline Mild: & requiring reassurance only \\
\hline Moderate: & $\begin{array}{l}\text { requiring treatment in specialist department } \\
\text { requiring admission for observation }\end{array}$ \\
\hline Severe: & requiring admission for several days \\
\hline
\end{tabular}

Table 2 Assessment of severity of injuries by researcher and second assessor

\begin{tabular}{llcrr}
\hline $\begin{array}{l}\text { Second } \\
\text { assessment }\end{array}$ & \multicolumn{2}{l}{$\begin{array}{l}\text { Researchers assessment } \\
\text { No }(\% \text { of total No) }\end{array}$} & \multirow{2}{*}{ Total } \\
& Mild & Moderate & Severe & \\
\hline Mild & $106(26)$ & $28(7)$ & $5(1)$ & $139(35)$ \\
Moderate & $34(8)$ & $117(29)$ & $24(6)$ & $175(43)$ \\
Severe & $6(2)$ & $13(3)$ & $69(17)$ & $88(22)$ \\
\hline Total & $146(36)$ & $158(39)$ & $98(24)$ & $402(100) \cdot(0)$ \\
\hline
\end{tabular}


Table 3 Type of accident and severity of injury

\begin{tabular}{lrrrr}
\hline $\begin{array}{l}\text { Type of } \\
\text { accident }\end{array}$ & \multicolumn{2}{l}{$\begin{array}{l}\text { Severity of injury } \\
\text { No (\%) }\end{array}$} & Total \\
\cline { 2 - 5 } & Mild & Moderate & Severe & \\
\hline Falls & $83(43)$ & $77(39)$ & $35(18)$ & 195 \\
Burns and scalds & $6(12)$ & $14(29)$ & $29(59)$ & 49 \\
Poisoning & $13(21)$ & $29(46)$ & $21(33)$ & 63 \\
Cuts & $23(43)$ & $21(39)$ & $10(18)$ & 54 \\
Others & $21(51)$ & $17(42)$ & $3(7)$ & 41 \\
\hline Total & $146(36)$ & $158(39)$ & $98(24)$ & 402 \\
\hline
\end{tabular}

$\chi^{2}=54 \cdot 87$. DF8, $\mathrm{p}<\cdot 0001$

Table 4 Attendance from each electoral ward and severity of injury

\begin{tabular}{|c|c|c|c|c|}
\hline \multirow{2}{*}{$\begin{array}{l}\text { Attendance } \\
\text { rates/1000 } \\
\text { children aged } \\
0-4 \text { in the } \\
\text { electoral ward }\end{array}$} & \multicolumn{3}{|c|}{$\begin{array}{l}\text { Severity of injury } \\
\text { No }(\%)\end{array}$} & \multirow[t]{2}{*}{ Tota } \\
\hline & Mild & Moderate & Severe & \\
\hline$>50$ & $55(32)$ & $76(44)$ & 41 (24) & 172 \\
\hline $26-50$ & $70(42)$ & $56(34)$ & $41(25)$ & 167 \\
\hline$<25$ & $21(33)$ & $26(41)$ & $16(25)$ & 63 \\
\hline Total & $146(36)$ & $158(39)$ & $98(24)$ & 4() 2 \\
\hline
\end{tabular}

$\chi^{2}=5 \cdot 06$, DF $4, \mathrm{p}<0 \cdot 28$.

Table 5 Parent's country of birth and severity of injury

\begin{tabular}{|c|c|c|c|c|}
\hline \multirow{2}{*}{$\begin{array}{l}\text { Severity of } \\
\text { injury }\end{array}$} & \multicolumn{4}{|c|}{ Parent's country of birth } \\
\hline & $\begin{array}{l}\text { British } \\
\text { Isles }\end{array}$ & Asian & Caribbean & Others \\
\hline Mild & $69(38)$ & $48(38)$ & $17(28)$ & $12(39)$ \\
\hline Moderate & $64(35)$ & $56(44)$ & 24 (39) & $14(45)$ \\
\hline Severe & $50(27)$ & $23(18)$ & $20(33)$ & $5(16)$ \\
\hline Total & $183(100)$ & $127(100)$ & $61(100)$ & $31(100)$ \\
\hline
\end{tabular}

$\chi^{2}=8 \cdot 64$, DF6, $p<0 \cdot 19$.

Table 6 Parent's social class and severity of injury

\begin{tabular}{lllll}
\hline Social class & \multicolumn{2}{l}{ Severity of injury } & \\
\cline { 2 - 4 } & Mild & Moderate & Severe & Total \\
\hline I and II & $16(44)$ & $16(44)$ & $4(11)$ & 36 \\
III non-manual & $16(28)$ & $29(50)$ & $13(22)$ & 58 \\
III manual & $51(37)$ & $62(45)$ & $26(19)$ & 139 \\
IV & $31(39)$ & $24(30)$ & $25(31)$ & 80 \\
V & $17(34)$ & $17(34)$ & $16(32)$ & 50 \\
Not known & $15(38)$ & $10(26)$ & $14(36)$ & 39 \\
\hline Total & $146(36)$ & $158(39)$ & $98(24)$ & $402(10() \cdot(0)$ \\
\hline
\end{tabular}

$\chi^{2}=18 \cdot 39, \mathrm{DF}=10, \mathrm{p}<0 \cdot 05$. ing from each ward and the distribution or severity of injuries found (table 4).

There were minor but not significant variations in the severity of injuries among the ethnic groups; children of Caribbean born parents had a slightly larger number of severe accidents when compared with the other groups combined (table 5). In contrast, there was a definite association in the trend of severity of injuries and social class. Children with social class I and II parents had fewer severe injuries; these were more common in those from classes IV and V (table 6).

\section{Discussion}

The severity rating scale used in this study of accidents to children in the home was based on information gathered by a doctor from hospital records. The definitions took into account information gleaned at the time of first attendance at the accident department, and also information recorded subsequently. We know of no previous study that has compared agreement between two observers on the severity of injuries of such accidents. In this study the agreement was moderate and showed no systematic differences between the two observers.

We found little difference in severity when we analysed the accidents by ethnic group, but a strong trend towards more severe injuries in lower social classes. This finding is in line with other results from our study that show that social class, but not race, is strongly associated with the frequency of accidents. ${ }^{13}$ Children from deprived families had more accidents, and these were more serious. It is of note that burns and scalds, and poisoning, were much more likely to be severe than the other types of accident. More research is needed to explore other factors affecting the severity of injuries.

The uniformity of proportions when severity was correlated with distance from the hospital was of interest. In this part of London there are several hospitals with catchment areas that overlap, so that access is probably not a major determinant of hospital use. Our severity scale for children who received treatment seems to reflect clinical thresholds that are important to patients at all distances in this population.

The number of accidents taken to hospital accident departments is not a complete measure of all accidents. Some, especially in rural areas, are treated by general practitioners, and many are self treated. What factors affect the likelihood of a parent taking a child to a hospital for treatment are complex, but include the time they expect to be kept waiting and the acceptability of the service. If the numbers of accidents dropped the service might 
improve, and parents might be prepared to take their children to hospital for more minor complaints. This 'iceberg' of morbidity prevents a simple conclusion being drawn merely from attendances as an evaluation of prevention. Only by monitoring the severity of injuries can this effect be considered

The Royal Society for the Prevention of Accidents has defined an accident as 'a consequence of a sequence of random events, always involving causal factors, with chance alone often determining the resultant severity.$^{15}$ By this definintion an effective plan for prevention of accidents to children would show a reduction in the total number of children attending a hospital after accidents, but without a change in the distribution of the severity of injuries. Many people, however, would intuitively regard this as unlikely. Young children are exploring the world and need a graded experience of risks; some accidents will always occur. A plan for the prevention of accidents to children would be as likely to seek to reduce the severity of the injuries as to reduce their frequency.

Our child injury severity scale showed relatively similar numbers of children in the three groups mild, moderate, and severe. This is in contrast to the pyramidal shape found in some other studies, with few severe accidents, more moderate ones, and many mild ones. ${ }^{69}$ There are two reasons for this finding. Firstly, we selected only children who needed medical treatment for the study. This process excluded the mildest injuries that required no medical treatment. Secondly, the scale was designed to create a range of severity that reflected the range of clinical cases, as Illingworth's was. We could have created a scale that designated only a small group as severe, in the way that the abbreviated injury scale seems to do, but this seemed less useful than one with a larger group designated severe if the eventual use of a scale would be to measure changes in rates of severity; if the severe group is initially small there would be little to change.

Accidents to children show a downward gradient when correlated with social class. Our study has shown that there is also a social class gradient of severity of injuries, but little difference in severity among ethnic groups. It suggests that strategies for prevention of childhood accidents will need to give special attention to the disadvantaged in our society. Plans that affect everyone equally (such as engineering regulations) or that communicate broadly (such as health education through the media) could, paradoxically, keep these inequalities persisting. Our study gives supporting evidence for the continuing need for positive discrimination in material and personal help for disadvantaged families if we are to make a noticeable impact on the number of accidents to children in the home. ${ }^{16}$

We are grateful to the staff of Brent Health Authority who helped with this study, and especially to Mr Subash Tachakra, consultant in charge of the accident and emergency department. Central Middlesex Hospital.

\section{References}

' Jackson RH. Wilkinson AW. Why don't we prevent childhood accidents? Br Med J 1976;i:1258-62.

Butler $N$. Child health and education in the seventies: some results on the five year follow up of the 1970 British Birth Cohort. Health Visitor 1980:53:81-2.

3 Consumer Safety Unit. The home accident surveillance system: analysis of domestic accidents to children. London: Department of Prices and Consumer Protection, 1979.

+ Murdoch R. Eva J. Home accidents to children under 15 years: survey of 910 cases. Br Med J 1974:3:103-6.

Nathorst-Westfelt JAR. Environmental factors in childhood accidents: a prospective study in Goteborg. Sweden. Acta Pediatr Scand 1982:291(suppl): 1-75.

"Rivara FP. Epidemiology of childhood injuries. Am J Dis Child 1982:136:399-405.

Stewart-Brown S. Peters TJ, Golding J. Bijur P. Case definition in childhood accident studies: a vital factor in determining results. Int J Epidemiol 1986:15:352-9.

" Maddocks GB, Sibert J. Brown BM. A four week study of accidents to children in South Glamorgan. Public Health 1978:92:171-6.

"Mever RJ. Roclofs HA. Bluestone J. Redmond S. Accidental injury to the pre school child. J Pediatr 1963;63:95-105.

1" Committee on Medical Aspects of Automotive Safety. Rating the severity of tissue damage 1: the abbreviated scale. JAMA 1971:215:277-80.

1 Illingworth C. Brennan P. Jay A. Al-Rawi F. Collick M. 200 injuries caused by playground equipment. $\mathrm{Br}$ Med J 1975:4: $3.32-4$.

12 Alwash RH. Child home accidents in a London borough: a study of their frequency in ethnic groups and the environmental association. London: University of London. 1987. $262 \mathrm{pp}$. (Thesis.)

1. Alwash RH. McCarthy M. Home accidents in children under five: are there ethnic group or social class differences? Br Med J (in press).

${ }^{14}$ Fleiss JL. Statistical methods for rates and proportions. New York: John Wiley, 1977:212-36.

15 Roval Society for the Prevention of Accidents. The facts about accidents. London: RoSPA Safety Education. 1981.

16. Townsend P. Davidson N. eds. Inequalities in health: the Black report. Harmondsworth: Penguin Books. 1982.

Correspondence to Dr M McCarthy, Department of Community Medicine, University College London, 66-72 Gower Street, London WC1E 6EA.

Accepted 11 December 1987 